|| ISSN(online): 2589-8698 || ISSN(print): 2589-868X ||

International Journal of Medical and Biomedical Studies

Available Online at www.ijmbs.info

NLM (National Library of Medicine ID: 101738825)

Index Copernicus Value 2019: 79.34

Original Research Article

Volume 5, Issue 7; July: 2021; Page No. 07-09

\title{
TO STUDY THE PATTERN OF VARIOUS CERVICAL LESION
}

\author{
Dr. Seema Gupta ${ }^{1}$, Dr. Deepali Jain ${ }^{2}$, Dr. Shweta Khandelwal ${ }^{3}$
}

${ }^{1-2}$ Associate Professor, Department of Pathology, JLN Medical College, Ajmer, Rajasthan

${ }^{3}$ Assistant Professor, Department of Pathology, JLN Medical College, Ajmer, Rajasthan

Article Info: Received 18 April 2021; Accepted 24 June 2021

DOI: https://doi.org/10.32553/ijmbs.v5i7.1999

Corresponding author: Dr. Deepali Jain

Conflict of interest: No conflict of interest.

\section{Abstract}

Background: Cancer of the cervix is an increasing health problem and an important cause of mortality in women worldwide. The incidence of cervical cancer arises worldwide.

Methods: A retrospective study was conducted in the Department of Pathology, JLN Medical College \& Hospital Ajmer.

Results: A total of 100 smears were analyzed. Out of which $96.00 \%$ smears were satisfactory for evaluation. Out of $96.00 \%$ satisfactory smears, $30.00 \%$ shows normal smear and $52.00 \%$ shows benign cellular changes and $4.00 \%$ shows epithelial cells abnormality. 5.00\% smears shows Bacterial vaginosis. $45.00 \%$ were inflammatory smears.

Conclusion: We concluded that cervical cytology by Pap smear is a simple, safe and effective test to detect premalignant and malignant lesions of cervix at an early stage, and thus help the clinicians in early and more efficient management of the patients.

Keywords: Pap smear, Cervix, Cytology.

\section{Introduction}

Cancer of the cervix is an increasing health problem and an important cause of mortality in women worldwide. The incidence of cervical cancer arises worldwide. The difference in incidence between developing and developed countries, where cervical cancer cases have been significantly reduced, is large. In developing countries like India, the burden of cervical cancer is still high. According to the World Cancer statistics, $>80 \%$ of all the cervical cancer cases are found in developing and low-resource countries, because of a lack of awareness and difficulty in running cytology-based screening programs. ${ }^{1}$ More than one-fifth of all cervical cancer deaths occur in India. Every year, 122,844 women in India are diagnosed with cervical cancer, and 67,477 women die from the disease. ${ }^{2}$

Unlike most other malignancies, cancer of cervix is readily preventable when effective programmes are conducted to detect and treat its precursor lesions. Since the introduction of Pap test, a dramatic reduction has been observed in the incidence and mortality of invasive cervical cancer worldwide. ${ }^{3}$

\section{Materials and methods}

A retrospective study was carried out in the department of pathology, JLN Medical College, AJmer

\section{Selection Criterion:}

\section{Inclusion criteria:}

1. Cervical cytology samples from all the females of age

21 years and above attending the obstetrics and gynaecology out patient Department with presenting complaints of white discharge per vagina, bleeding per vagina, post-coital bleeding, irregular menstruation and for routine cervical cancer screening.

\section{Exclusion criteria-}

1. Non co-operative patients.

2. Patients who do not give consent.

3. Patients with massive bleeding per vagina.

4. Treated cervical carcinoma patients.

5. Pregnant women.

The cases were examined in detail and findings recorded on the standard proforma. First a careful history of the patient taken, complaints noted in the order of importance and duration. A detailed obstetric, menstrual, contraceptive history noted.

\section{Methodology}

- After obtaining approval and clearance from the institutional review board, only those patients meeting the inclusion and exclusion criteria enrolled for the study.

- Informed consent obtained from each participant.

- After obtaining proper consent, proforma was given to each patient and detailed history was obtained. After that, physical examination was done and the patient was put in lithotomy position for specimen collection.

\section{Data analysis}

Data was recorded as per Performa. The data analysis was computer based; SPSS-22 was used for analysis. For 
categoric variables chi-square test was used. For continuous variables independent samples's $t$-test was used. $p$-value
$<0.05$ was considered as significant.

Results

Table 1: Analysis of pap smear

\begin{tabular}{|l|l|l|}
\hline Pap Smear & Total No. & $\%$ \\
\hline Total Smears & 100 & 100 \\
\hline $\begin{array}{l}\text { I. Adequacy of smears } \\
\text { Satisfactory for evaluation } \\
\text { Unsatisfactory for evaluation }\end{array}$ & 96 & 96.00 \\
\hline $\begin{array}{l}\text { II. General categorization } \\
\text { Normal smears }\end{array}$ & 4 & 4.00 \\
\hline Benign cellular changes & 30 & 30.00 \\
\hline $\begin{array}{l}\text { i. Specific Infections } \\
\text { Bacterial vaginosis }\end{array}$ & 52 & 52.00 \\
\hline $\begin{array}{l}\text { ii. Reactive Changes } \\
\text { Inflammatory smears } \\
\text { Atrophic smears }\end{array}$ & 5 & 5.00 \\
\hline $\begin{array}{l}\text { C. Epithelial cells abnormality } \\
\text { i. Atypical epithelial cells } \\
\text {-Atypical squamous cells } \\
\text { of undetermined } \\
\text { significance (ASCUS). } \\
\text {-Atypical squamous cells } \\
\text { cannot exclude HSIL (ASC-H) } \\
\text {-Atypical glandular cells of } \\
\begin{array}{l}\text { Undetermined } \\
\text { Significance (AGUS). }\end{array}\end{array}$ & 45 & 45.00 \\
\hline $\begin{array}{l}\text { ii. Low grade squamous } \\
\text { intraepithelial lesion } \\
\text { (LSIL) }\end{array}$ & 2 & 1.00 \\
\hline $\begin{array}{l}\text { iii. High grade squamous } \\
\text { intraepithelial lesion } \\
\text { (HSIL) }\end{array}$ & 1 & 2.00 \\
\hline $\begin{array}{l}\text { iv. Malignancy- Squamous cell } \\
\text { carcinoma }\end{array}$ & 1 & 1.00 \\
\hline
\end{tabular}

A total of 100 smears were analyzed. Out of which $96.00 \%$ smears were satisfactory for evaluation. Out of $96.00 \%$ satisfactory smears, $30.00 \%$ shows normal smear and $52.00 \%$ shows benign cellular changes and $4.00 \%$ shows epithelial cells abnormality. 5.00\% smears shows Bacterial vaginosis. $45.00 \%$ were inflammatory smears.

\section{Discussion}

Cancer cervix is a leading cause of mortality and morbidity in developing countries like India most probably due to lack of proper screening facilities in the rural and suburban areas or due to the lack of awareness amongst the women of developing countries. Cervical cancer is the fourth most common cancer in the world. Developing countries accounted to about $80 \%$ of the global burden. Cervical cancer is the second most common cancer in women in India. ${ }^{4}$
So detection of its premalignant lesions is of utmost importance, which can be easily done by screening methods. The mainstay of cervical cancer screening is Papnicolaou (Pap) smear. Morbidity and mortality from cervical cancers have been shown to decrease substantially by the proper implementation of screening methods.

A Pap smear is a useful and an important method for cervical cancer screening. Worldwide, there have been efforts to prevent cervical cancer by screening women using PAP smears and thereby detecting and treating the precancerous lesions. Cervical cancer incidence can be reduced by as much as $90 \%$ in a population undergoing regular screening and having high quality and coverage. ${ }^{63}$ However, in developing countries, due to lack of education and awareness, many women have never had a Pap smear. Thereby, proper implementation of screening program is the need of the hour. 
A total of 100 smears were analyzed. Out of which $96.00 \%$ smears were satisfactory for evaluation. Out of $96.00 \%$ satisfactory smears, $30.00 \%$ shows normal smear and $52.00 \%$ shows benign cellular changes and $4.00 \%$ shows epithelial cells abnormality. 5.00\% smears shows Bacterial vaginosis. $45.00 \%$ were inflammatory smears.

Khattak et al. ${ }^{5}$ and Sherwani et al., ${ }^{6}$ found LSIL and HSIL on cytology to be more prevalent in patients who started sexual activity before 20 years of age.

Present study emphasized the significance of vaginal discharge and its association with neoplastic changes in the cervix. The results correspond with many previous studies. ${ }^{7}$

\section{Conclusion}

We concluded that cervical cytology by Pap smear is a simple, safe and effective test to detect premalignant and malignant lesions of cervix at an early stage, and thus help the clinicians in early and more efficient management of the patients.

\section{References}

1. Parkin DM, Pisani, Ferley S. Estimates of the worldwide incidence of 25 major cancers in 1999. Int J Cancer 1999;80(6):827-41.
2. Cancer incidence in five continents. International agency for research on cancer LYON $1990 \mathrm{vol}$

3. National cancer registry programme. An epidemiological study, ICMR New Delhi. Consolidated report of population based cancer registries 2001-2004, Consolidated report of hospital based cancer registries 2001-2003.

4. Zarchi MK, Peighmbari F, et al. A Comparison of 3 Ways of Conventional Pap Smear, Liquid Based Cytology and Colposcopy vs Cervical Biopsy for Early Diagnosis of Premalignant Lesions or Cervical Cancer in Women with Abnormal Conventonal Pap Test. Int J Biomed Sci 2013;9(4):205-210.

5. Khattak ST, Khattak I, Naheed T, Akhtar S, Jamal T. Detection of abnormal cervical cytology by pap smears. Gomal J Med Sci. 2006;4:74-7.

6. Sherwani RK, Khan T, Akhtar K, Zeba A, Siddiqui FA, Rahman K, et al. Conventional Pap smear and liquid based cytology for cervical cancer screening - A comparative study. J Cytol. 2007;24:167-72.

7. Pradhan N, Giri K, Rana A. Cervical cytology study in unhealthy and healthy looking cervix. $N \mathrm{~J}$ Obstet Gynaecol. 2007;2:42-7. 